\title{
KAJIAN PERTUMBUHAN DAN PERSEBARAN AWAN HUJAN PADA SAAT BANJIR BERBASIS DATA SATELIT HIMAWARI-8 (Studi Kasus : Banjir di Kab. Kerinci dan Kota Sungai Penuh 4 Juni 2020)
}

\author{
IQBAL GUSRANDA ${ }^{1, *}$, MARIA OCTAVIA ROSNAULI HUTAGALUNG ${ }^{1}$, NADHILAH \\ HUMAIRAH SALWA SALSABIL ${ }^{1}$, ADITYA MULYA ${ }^{2}$ \\ ${ }^{1}$ Program Studi Meteorologi, Sekolah Tinggi Meteorologi Klimatologi dan Geofisika (STMKG) \\ Jl. Perhubungan I No. 5 Komplek BMKG Pondok Betung Bintaro, Pondok Aren, Tangerang \\ Selatan, Banten Kode Pos 15221, Telp.(021) 73691621 \\ ${ }^{2}$ Sekolah Tinggi Meteorologi Klimatologi dan Geofisika (STMKG) \\ Jl. Perhubungan I No. 5 Komplek BMKG Pondok Betung Bintaro, Pondok Aren, Tangerang \\ Selatan, Banten Kode Pos 15221, Telp.(021) 73691621
}

*email : iqbal.gusranda@stmkg.ac.id

\begin{abstract}
Abstrak. Telah terjadi banjir besar di Kabupaten Kerinci dan Kota Sungai Penuh Provinsi Jambi pada tanggal 4 Juni 2020. Banjir diakibatkan oleh intensitas curah hujan yang tergolong hujan lebat yamg terjadi di wilayah kajian dan sekitarnya. Dampak yang ditimbukan oleh banjir tersebut ialah ribuan rumah terkonfirmasi terendam banjir dan lumpuhnya aktivitas manusia pada kawasan yang terdampak. Berdasarkan hal tersebut maka dilakukan penelitian untuk mengkaji dinamika atmosfer diantaranya kondisi suhu permukaan laut, mean sea level pressure, streamline, jumlah curah hujan, dan data citra satelit Himawari-8 pada tanggal kejadian. Data diolah dalam bentuk grafik dan peta spasial kemudian dilakukan analisis deskriptif. Berdasarkan hasil analisis, hujan lebat yang terjadi di wilayah Kabupatan Kerinci dan Kota Sungai Penuh dipengaruhi oleh suhu permukaan laut, mean sea level pressure, dan streamline yang mendukung terbentuknya awan konvektif. Terjadinya hujan lebat seringkali terkait dengan keberadaan awan Cumulonimbus $(\mathrm{Cb})$. Hal ini dikarenakan awan $\mathrm{Cb}$ identik dengan dimensi yang besar serta mengandung banyak partikel presipitasi seperti uap air dan kristal es. Berdasarkan pengamatan awan melalui satelit himawari-8 diketahui bahwa, hampir seluruh awan hujan yang muncul saat tanggal kejadian merupakan awan $\mathrm{Cb}$ yang mempunyai nilai suhu puncak awan terendah mencapai nilai $-82.5^{\circ} \mathrm{C}$.
\end{abstract}

Kata kunci: hujan lebat, banjir, cumulonimbus, satelit Himawari-8

Abstract. Major floods occurred in Kerinci Regency and Sungai Penuh City, Jambi Province on June 4, 2020. The flooding was caused by the intensity of rainfall which was classified as heavy rain that occurred in the study area and its surroundings. The impact of the flood is that thousands of houses are confirmed to be flooded and human activities are paralyzed in the affected area. Based on this, a study was conducted to examine the dynamics of the atmosphere which includes sea surface temperature conditions, average sea surface pressure, streamline, rainfall amount, and Himawari-8 satellite imagery data on the date of the incident. The data is processed in the form of graphs and spatial maps and then descriptive analysis is carried out. Based on the results of the analysis, heavy rain that occurred in Kerinci Regency and Sungai Penuh City is influenced by sea surface temperature, average sea surface pressure, and current lines that support the formation of convective clouds. The occurrence of heavy rain is often associated with the presence of Cumulonimbus $(\mathrm{Cb})$ clouds. This is because $\mathrm{Cb}$ clouds are identical with large dimensions and contain many precipitation particles such as water vapor and ice crystals. Based on cloud observations via the Himawari-8 satellite, it is known that almost all the 
rain clouds that appeared on the date of the incident were $\mathrm{Cb}$ clouds which had the lowest cloud top temperature value reaching $-82.5^{\circ} \mathrm{C}$.

Keywords: heavy rain, flood, cumulonimbus, Himawari-8 satellite

\section{Pendahuluan}

Banjir di defenisikan sebagai tergenangnya suatu tempat akibat meluapnya air yang melebihi kapasitas pembuangan air disuatu wilayah dan menimbulkan kerugian fisik, sosial dan ekonomi [1]. Banjir adalah ancaman musiman yang terjadi apabila meluapnya tubuh air dari saluran yang ada dan menggenangi wilayah sekitarnya. Banjir adalah ancaman alam yang paling sering terjadi dan paling banyak merugikan, baik dari segi kemanusiaan maupun ekonomi [2].

Pada tanggal 4 Juni 2020 telah terjadi hujan lebat di wilayah Kabupaten Kerinci dan Kota Sungai Penuh. Kejadian ini mengakibatkan beberapa wilayah tergenang banjir. Diinfokan bahwa ribuan rumah dilaporkan terendam banjir diantaranya terjadi di 6 kecamatan di Kabupaten Kerinci dan 3 kecamatan di Kota Sungai Penuh [3]. Banjir dapat disebabkan oleh limpasan air permukaan (runoff) yang meluap dan volumenya melebihi kapasitas pengaliran sistem drainase atau sistem aliran sungai [4]. Dengan melihat dampak yang ditimbulkan perlu dilakukan analisis untuk mengetahui penyebab kejadian hujan lebat yang berdampak banjir pada 4 Juni 2020 dengan melihat karakteristik awan dan hujan dalam periode kejadian.

Salah satu instrumen yang dapat digunakan untuk mengidentifikasi awan konvektif atau awan yang berpotensi menimbulkan hujan adalah Satelit Himawari-8. Satelit ini merupakan satelit cuaca meteorologi geostasioner yang merupakan generasi penerus satelit MTSAT 2 yang diluncurkan pada tahun 2015 oleh JMA yang berfungsi untuk mengamati parameter meteorologi, antara lain untuk mengamati perkembangan awan Cumulonimbus. Satelit ini memiliki 16 kanal yang terdiri dari kanal Visibel, Near-IR, IR WV, SW IR, dan LW IR. Satelit ini menyediakan data citra pengamatan setiap 10 menit sehingga dapat memberikan atau menggambarkan perkembangan fenomena meteorologi seperti awan Cumulonimbus secara komprehensif [5].

Hasil pengukuran curah hujan di Stasiun Meteorologi Depati Parbo pada periode Kamis, 4 Juni 2020 tinggi curah hujan mencapai $58 \mathrm{~mm}$ dan masuk dalam kategori hujan lebat. Hujan lebat adalah hujan dengan intensitas minimum $50 \mathrm{~mm} / 24$ jam atau $20 \mathrm{~mm} /$ jam [6].

Jurnal ini ditulis dengan tujuan untuk mengetahui kondisi sebaran awan saat sebelum, sesaat, dan setelah hujan yang menyebabkan banjir di wilayah kajian.

\section{Metode Penelitian}

\subsection{Lokasi Penelitian}

Lokasi penelitian ini mengambil daerah studi di wilayah Kabupaten Kerinci dan Kota Sungai Penuh dan sekitarnya sebagai wilayah yang terkena dampak dari hujan lebat tersebut dengan lokasi titik koordinat $1^{\circ} 40^{\prime}-2^{\circ} 20^{\prime}$ LS dan $101^{\circ} 08^{\prime}-101^{\circ}$ 50 ' BT. 


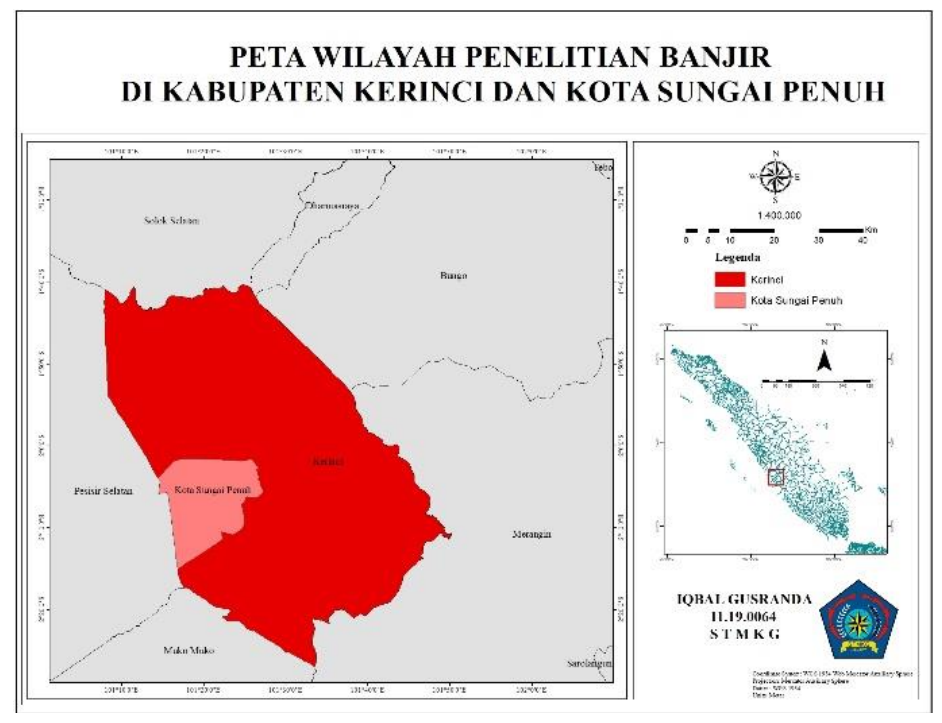

Gambar 1. Peta Wilayah Penelitian

\subsection{Data dan Metode}

Data yang digunakan dalam penelitian ini diantaranya merupakan data hasi pengamatan curah hujan pada tanggal 4 Juni 2020 yang diperoleh dari Stasiun Meteorologi Kelas III Depati Parbo - Kerinci.

Raw data satelit Himawari-8 yang digunakan adalah kanal 8, 13, dan 15 yang diperoleh dari database $\mathrm{BMKG}$, dengan format sataid yang memiliki resolusi temporal tiap 10 menit untuk menampilkan produk peringatan dini cuaca signifikan dari awan $\mathrm{Cb}$ [7]. Kanal 13 dan 15 merupakan kanal IR yang digunakan untuk melihat suhu puncak awan dan identifikasi awan pada kejadian di lokasi penelitian pada tanggal 4 Juni 2020, Lalu kanal 8 merupakan kanal Water Vapor yang digunakan untuk melihat uap air. Raw data satelit diolah dengan menggunakan software GMSLPD. Hasil pengolahan ini berupa citra suhu puncak awan secara spasial dengan satuan derajat Celcius $\left({ }^{\circ} \mathrm{C}\right)$, guna melihat perkembangan suhu puncak awan untuk analisis pembentukan awan dan untuk melihat kontur awan.

Data Reanalysis pada tanggal 4 Juni 2020 dalam bentuk Network Common Data Form (netCDF). Data tersebut diakses secara interaktif melalui NOAA Physical Sciences Laboratory di alamat https://psl.noaa.gov/cgi-bin /db_search/SearchMenus.pl, meliputi: sea surface temperature berupa data NOAA High-resolution Blended Analysis Daily Mean dan mean sea level pressure berupa data NCEP/DOE AMIP-II Reanalysis (Reanalysis-2) 4 Time Daily Individual Obs. Database BMKG meliputi data streamline. Aplikasi Grads digunakan untuk mengolah dan menampilkan data Reanalisis tersebut. Metode yang digunakan dalam penelitian ini adalah metode deskriptif analitis baik pada hasil tampilan citra satelit maupun pemodelan data Grads. Setelah data diolah, maka analisis data dilakukan dengan metode life history. Metode life history digunakan untuk menjelaskan waktu tahapan pertumbuhan awan konvektif. Perkembangan awan konvektif dapat dilihat secara rinci dengan memerhatikan waktu hidup per fase dan pergerakannya dari koordinat sel. Model output Grads menjadi pedoman untuk menggambarkan kondisi dinamis atmosfer. 


\section{Hasil dan Pembahasan}

Curah hujan yang ditakar di Stasiun Meteorologi Kelas III Depati Parbo Kerinci pada periode 4 Juni 2020 akumulasi 24 jam ialah $58 \mathrm{~mm}$. Dengan nilai curah 58 $\mathrm{mm}$, hujan pada kondisi tersebut digolongkan ke dalam kategori hujan lebat.

Sea surface temperature (SST) merupakan salah satu parameter yang digunakan untuk melihat keadaan suhu permukaan laut untuk mendukung terjadinya konvektivitas atau pertumbuhan awan konvektif. Terpantau di sebelah utara Kepulauan Riau dan Bangka belitung suhu berkisar $30-31^{\circ} \mathrm{C}$ yang mana suhu tersebut mendukung untuk pertumbuhan awan konvektif.
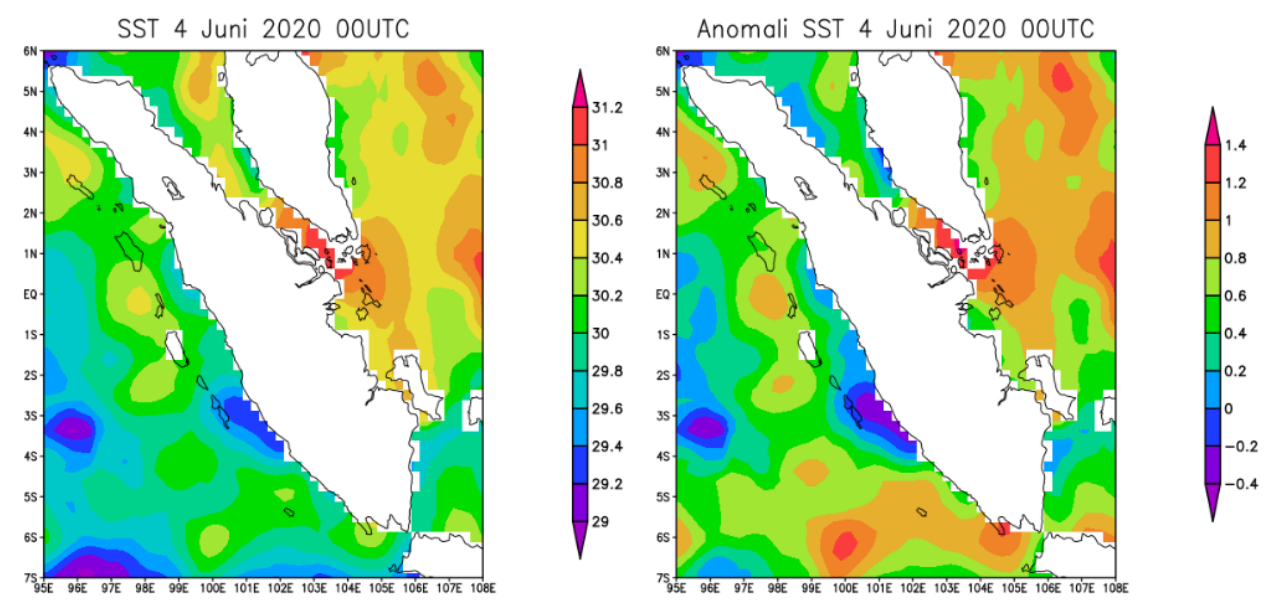

Gambar 2. Sea Surface Temperature dan Anomali Sea Surface Temperature 4 Juni 2020 jam 00 UTC

Lalu berdasarkan nilai anomali sea surface temperature diketahui bahwa nilai anomali SST positif di kisaran $0,6-1,4^{\circ} \mathrm{C}$ di wilayah Kepulauan Riau dan Bangka Belitung sehingga dengan keadaan ini mendukung untuk terbentuknya awan konvektif.

Mean Sea Level Pressure (MSLP) merupakan salah satu parameter yang juga digunakan untuk melihat kondisi dan distribusi dari awan konvektif. Pada jam 00 06 UTC terlihat di wilayah Kabupaten Kerinci dan Kota Sungai Penuh terdapat tekanan rendah sebesar 1010,1 mBar dan pada jam 06 UTC sebesar 1011,0 mBar. Hal ini menunjukkan pada periode waktu tersebut bahwa wilayah kajian berpotensi menjadi daerah penumpukan awan yang dapat menghasilkan awan - awan konvektif penyebab hujan. Pada jam $06-12$ UTC tekanan tinggi berdistribusi ke daratan yang tentunya menghasilkan angin yang dapat menggerakan awan hasil konvektivitas. Lalu pada jam 12 - 18 UTC tekanan tinggi berada di sekitar daratan dan pesisir selatan Sumatera Barat. 

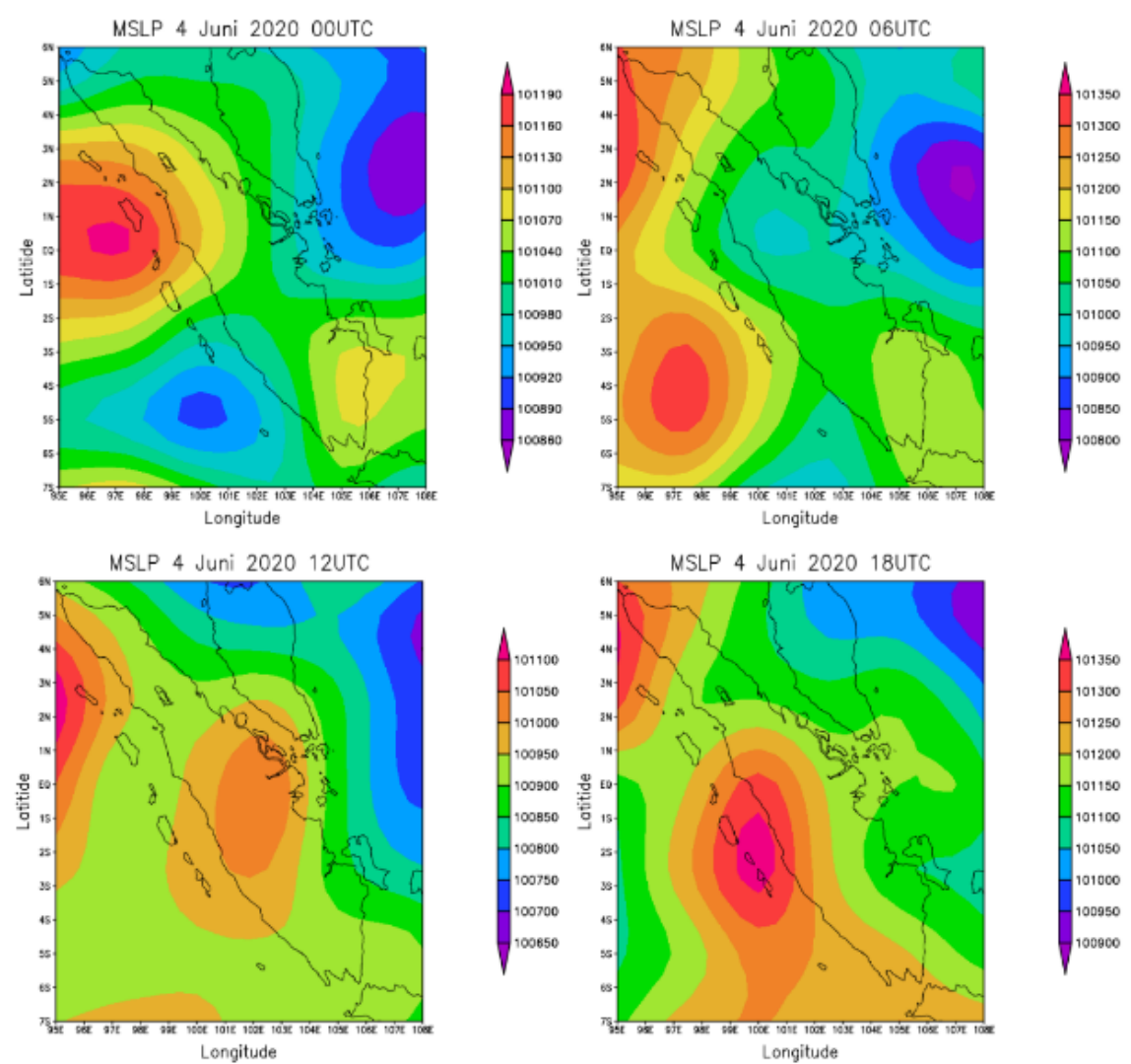

Gambar 3. Mean Surface Level Temperature 4 Juni 2020
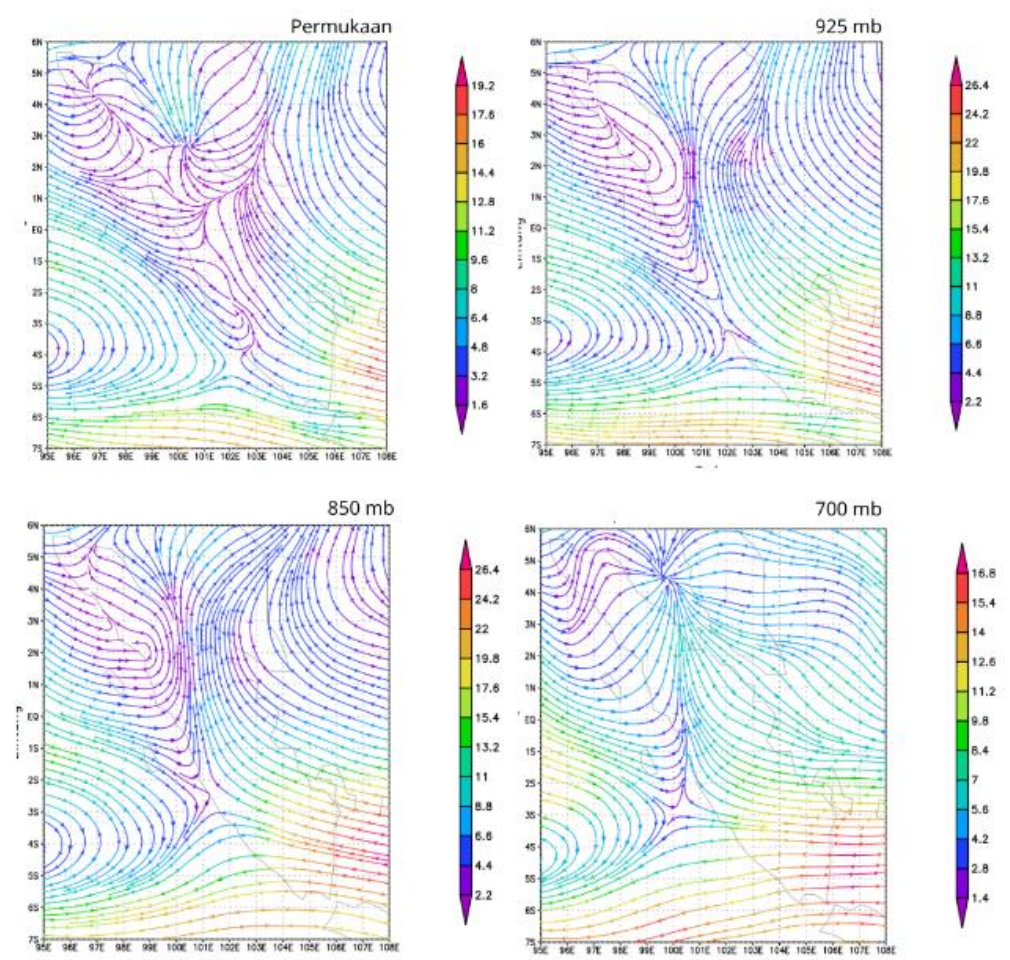

Gambar 4. Streamline Lapisan Permukaan, 925 mBar , 850 mBar , dan 700 mBar 4 Juni 2020 
Berdasarkan output streamline angin lapisan permukaan, $925 \mathrm{mBar}, 850 \mathrm{mBar}$, 700 mBar jam 06 UTC terdapat pembelokan angin di daerah sekitar lokasi penelitian. Dengan adanya pembelokan dan pertemuan angin dapat menimbulkan penumpukan awan yang selanjutnya berpotensi menghasilkan awan konvektif di lokasi penelitian.

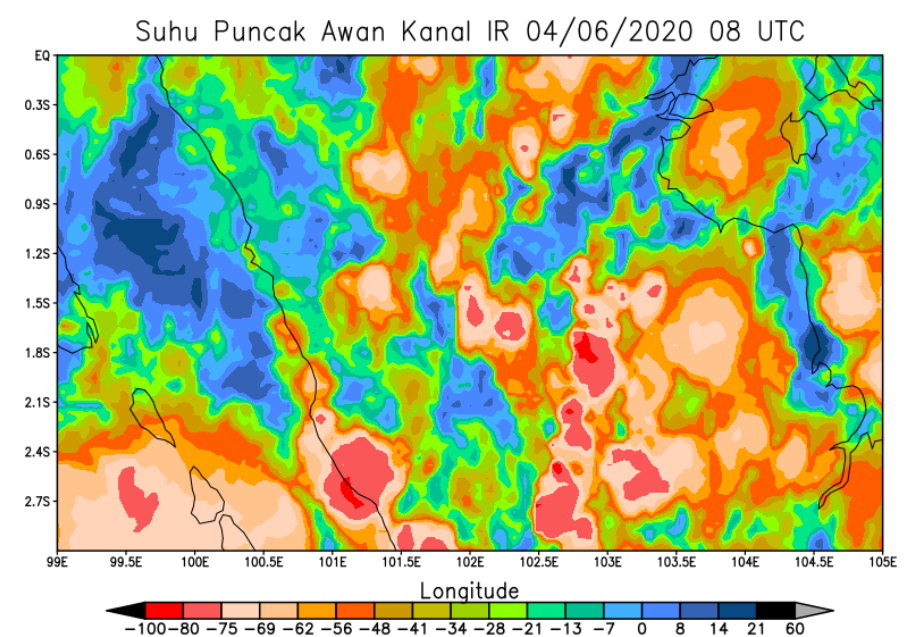

Gambar 5. Suhu Puncak Awan dengan suhu dingin mulai muncul

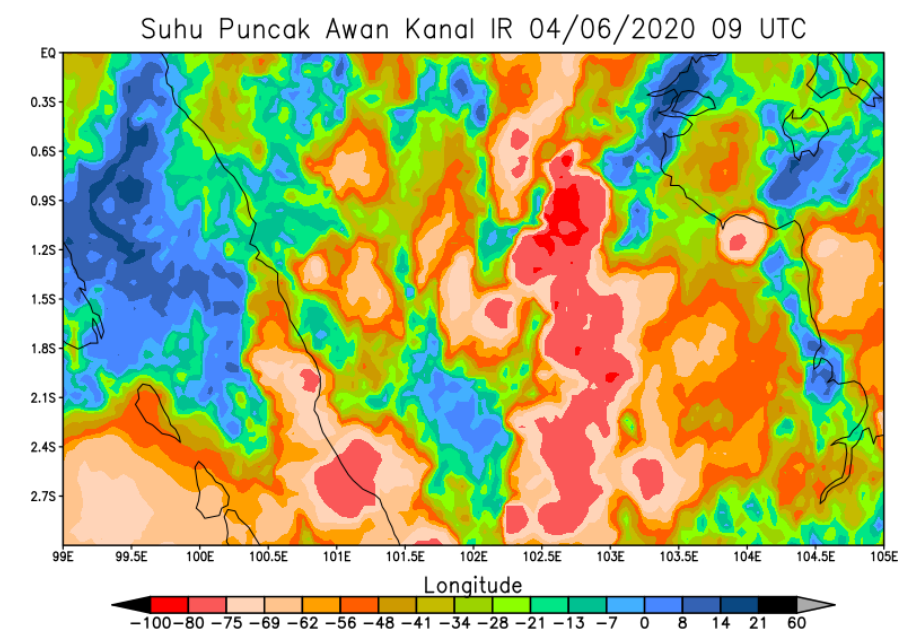

Gambar 6. Suhu Puncak Awan dengan suhu dalam fase tumbuh/berkembang

Berdasarkan gambar diatas, pada jam 08 UTC mulai menunjukkan adanya konvektifitas atau tumbuhnya awan berwarna merah atau konvektif di sekitar wilayah penelitian, hal ini disebut dengan fase pertumbuhan awan. Lalu pada jam $09-12$ UTC awan mulai tumbuh dan jenuh hingga matang dengan warna merah yang lebih padat. Lalu pada jam 12 - 15 UTC awan meluruh yang ditunjukkan dengan berubahnya warna merah di daerah kajian pada citra satelit. 


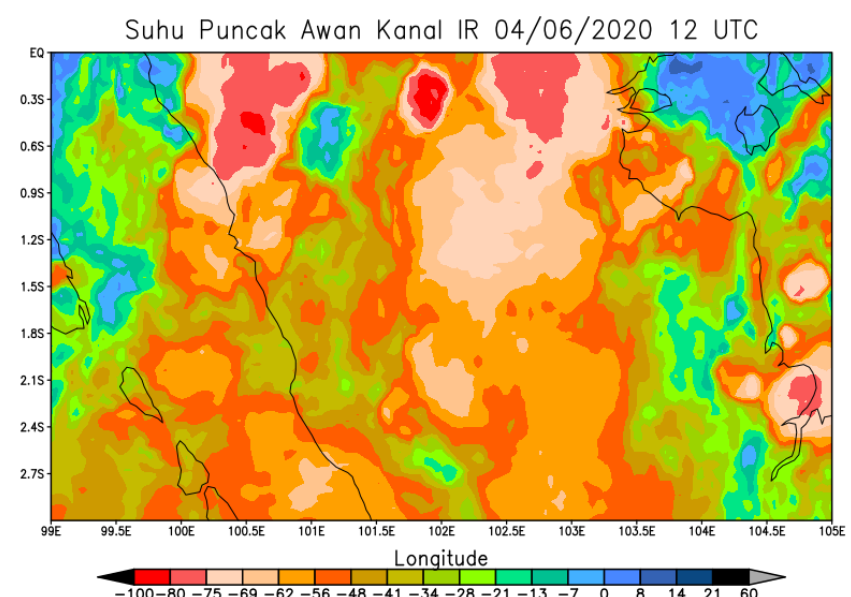

Gambar 7. Suhu Puncak Awan dengan suhu dalam fase matang

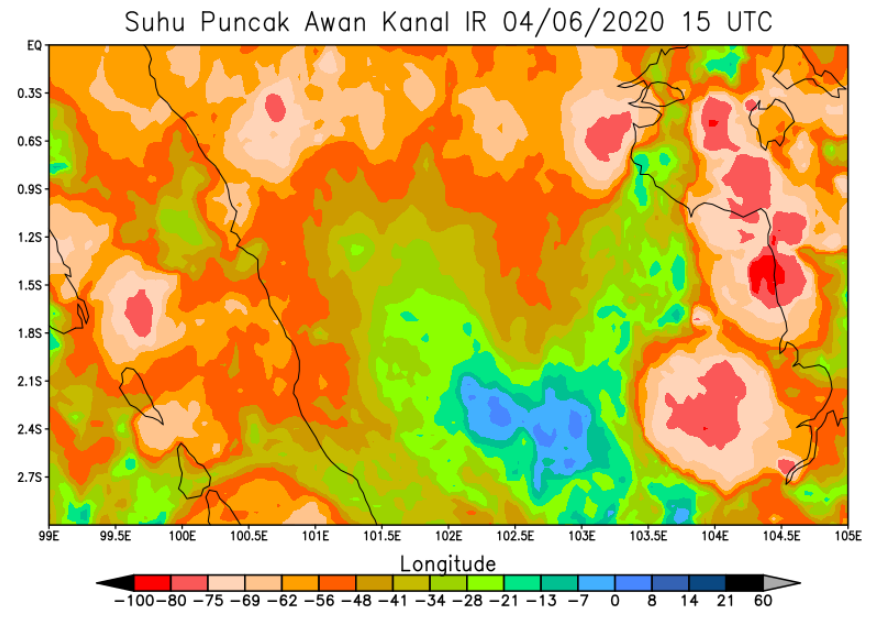

Gambar 8. Suhu Puncak Awan dalam fase meluruh

Berdasarkan grafik time series di wilayah penelitian tanggal 4 Juni 2020 jam 06 18 UTC sesuai dengan periode terjadinya banjir, terlihat pola pertumbuhan mulai terbentuk saat beberapa jam sebelum terjadinya hujan lebat. Pembentukan awan konvektif mulai terbentuk pada jam 08 UTC, dan berangsur mengalami fase pertumbuhan hingga suhu $-60^{\circ} \mathrm{C}$ pada jam 09 UTC. Pada jam $09-12$ UTC hampir suhu konstan di $-60^{\circ} \mathrm{C}$ yang menunjukan fase pematangan dari awan konvektif. Lalu pada jam 12 - 16 UTC peluruhan mulai terjadi atau presipitasi mulai turun hingga awan konvektif tersebut habis. Selama periode presipitasi, hujan dikategorikan lebat dengan hasil observasi penakaran jumlah hujan oleh stasiun observasi terdekat. 


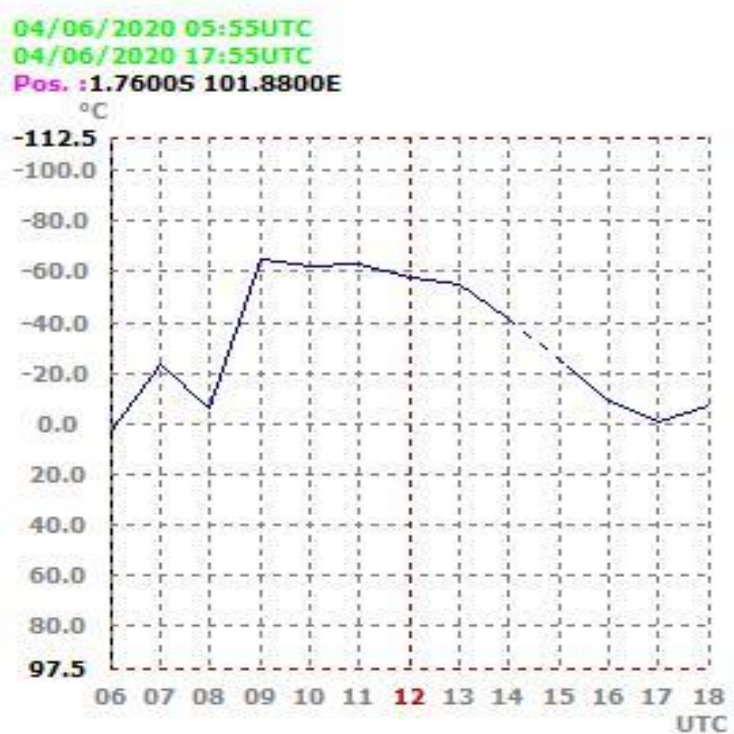

Gambar 9. Citra IR time series 06 - 18 UTC tanggal 4 Juni 2020

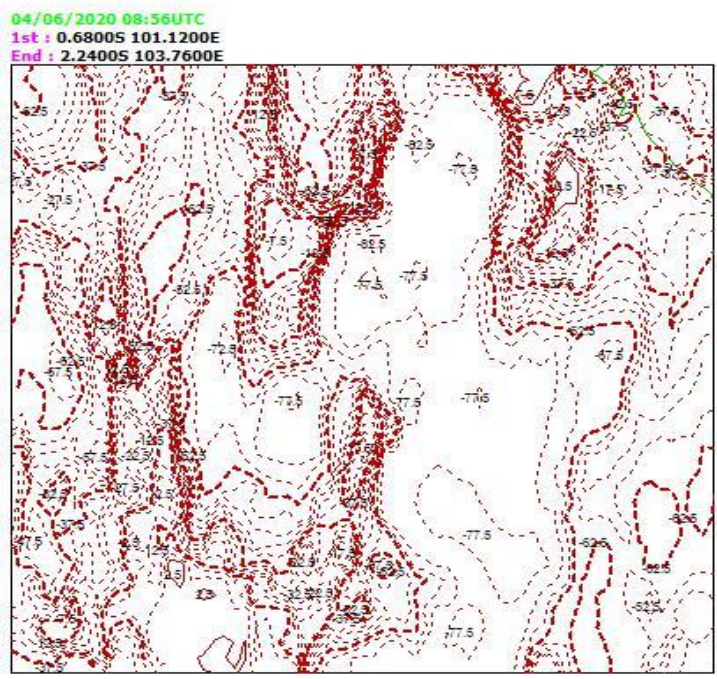

Gambar 10. Citra IR Countur 09 UTC tanggal 4 Juni 2020

Berdasarkan output kontur awan di sekitar daerah penelitian dan sekitarnya terlihat bahwa suhu puncak awan di wilayah tersebut mencapai $-77,5^{\circ} \mathrm{C}$ bahkan awan lain disekitarnya mencapai $-82,5^{\circ} \mathrm{C}$ dengan awan konvektif lebih dari satu di wilayah kajian. Dengan nilai suhu tersebut, diindikasikan bahwa awan-awan yang terbentuk di wilayah tersebut adalah awan-awan dingin yang merupakan awan Cumulonimbus. Awan tersebut dapat menghasilkan hujan ringan hingga hujan dengan intensitas yang sangat lebat.

\section{Kesimpulan}

Berdasarkan hasil dan pembahasan dapat disimpulkan bahwa pertumbuhan awan hujan yang mengakibatkan hujan dengan intensitas yang lebat di wilayah 
Kabupaten Kerinci, Kota Sungai penuh dan sekitarnya yang memberikan dampak banjir di 6 Kecamatan di Kabupaten Kerinci dan 3 Kecamatan di Kota Sungai Penuh dipengaruhi oleh beberapa aspek, diantaranya sea surface temperature, mean sea level pressure, dan kondisi angin yang mendukung terbentuknya awan konvektif. Hasil analisis penginderaan jauh dengan menggunakan satelit Himawari8 menunjukkan awan yang terbentuk yaitu awan Cumulonimbus dengan persebaran awan Cumulonimbus tampilan kontur lebih dari satu sel awan dengan suhu awan mencapai $-77,5$ s.d $-82,5^{\circ} \mathrm{C}$.

\section{Ucapan Terima Kasih}

Penulis mengucapkan terima kasih kepada Pak Aditya Mulya selaku dosen pembimbing, Pegawai BMKG Stasiun Meteorologi Kelas III Depati Parbo Kerinci, taruna/i STMKG yang terlibat, dan seluruh pihak yang ikut membantu dan memberikan akses data untuk menunjang penelitian ini.

\section{Daftar Pustaka}

1. H.P Rahayu dkk, Banjir dan Upaya Penanggulangannya, PROMISE Indonesia, Bandung, 2009.

2. IDEP, Panduan Umum Penanggulangan Bencana Berbasis Masyarakat Edisi ke-2, Yayasan IDEP, Bali, 2007.

3. JEKTV, Puluhan Ribu Rumah terendam Banjir di Kerinci dan Sungai Penuh, https://jektv.co.id/read/2020/06/05/1470/puluhan-ribu-rumah-terendambanjir-di-kerinci-dan-sungai-penuh/, 5 Juni 2020.

4. L. Sebastian, Pendekatan dan Penanggulangan Banjir, Dimanika Teknik Sipil, Vol. 8 (2008), p. 162-169.

5. Mahrifoh, Kajian Pemanfaatan Data Citra Satelit Himawari-8 Untuk Mendeteksi Awan Signifikan dari Awan Cumulonimbus, Skripsi, Tangerang Selatan, Sekolah Tinggi Meteorologi Klimatologi dan Geofisika, 2017.

6. BMKG, Prosedur Standar Operasi Pelaksanaan Peringatan Dini Pelaporan dan Diseminasi Informasi Cuaca Ekstrim, Badan Meteorologi Klimatologi dan Geofisika, Jakarta, 2010.

7. BMKG, Pedoman Operasional Penginderaan Citra Satelit Cuaca, Badan Meteorologi Klimatologi dan Geofisika, Jakarta, 2016. 